improvement of Narrative Writing Ability through Contextual Approach with School Environment Inspiration for Class VIII-1 Students of SMP Negeri 1 Brang Rea

\title{
Meningkatkan Kemampuan Menulis Karangan Narasi melalui Pendekatan Kontekstual dengan Inspirator Lingkungan Sekolah Siswa Kelas VIII-1 SMP Negeri 1 Brang Rea
}

\author{
Saerni \\ doi: https://doi.org/10.51518/lentera.v3i2.55
}

email: sakerni164@gmail.com

Guru Bahasa Indonesia pada SMP Negeri 1 Brang Rea - Kab. Sumbawa Barat

\begin{abstract}
This study aims to find out and reveal that the application of a contextual approach with school environment inspiration can improve the ability to write narrative essays for class VIII-1 students of SMP Negeri 1 Brang Rea, and find out and find contextual learning steps to improve narrative essay writing skills. The subjects of this study were students of class VIII-1 SMP Negeri 1 Brang Rea. This research uses a classroom action research design and was carried out in the 2018/2019 academic year, carried out in three cycles, in which the three cycles discussed one linguistic aspect, namely "writing narrative essays". Following the action research design, activities are carried out in each cycle, including planning, implementing actions, observing actions, and reflecting on actions and their results. The technique used in collecting data is the observation sheet technique and the test technique. The data were processed using qualitative descriptive techniques. Based on the results of data analysis, it turns out that the contextual approach can improve the quality of learning to write narrative essays for class VIII-1 students of SMP Negeri 1 Brang Rea, 2018/2019 academic year. This can be observed from the acquisition of the average score of students who experienced a significant increase. In the initial test results, the average score of students only reached 60 . The average score of students increased in the first cycle test to 68 , increased to 78 in the second cycle. The contextual approach can provide opportunities for students to compete in compiling narrative essays according to the characteristics of narrative essays. Changes in behavior or attitudes appear in learning to compose narrative essays.
\end{abstract}

Keywords: Writing narrative essay, contextual approach, school environment inspiration 


\begin{abstract}
Abstrak: Penelitian ini bertujuan untuk mengetahui dan mengungkap bahwa penerapan pendekatan kontekstual dengan inspirator lingkungan sekolah dapat meningkatkan kemampuan menulis karangan narasi siswa kelas VIII-1 SMP Negeri 1 Brang Rea, dan mengetahui serta menemukan langkah-langkah pembelajaran kontekstual untuk meningkatkan kemampuan menulis karangan narasi. Subyek penelitian ini adalah siswa kelas VIII-1 SMP Negeri 1 Brang Rea. Penelitian ini menggunakan rancangan penelitian tindakan kelas dan dilaksanakan pada tahun pelajaran 2018/2019, dilakukan dalam tiga siklus, yang pada ketiga siklus tersebut membahas satu aspek kebahasaan yakni "menulis karangan narasi". Sesuai dengan rancangan penelitian tindakan, pada setiap siklus dilakukan kegiatan yang meliputi perencanaan, pelaksanaan tindakan, observasi tindakan, refleksi tindakan dan hasil-hasilnya. Teknik yang digunakan dalam mengumpulkan data adalah dengan teknik lembar observasi dan teknik tes. Data diolah dengan menggunakan teknik deskriptif kualitatif. Berdasarkan hasil analisis data, ternyata pendekatan kontekstual dapat meningkatkan mutu pembelajaran menulis karangan narasi siswa kelas VIII-1 SMP Negeri 1 Brang Rea, tahun pelajaran 2018/2019. Hal ini dapat dicermati dari perolehan nilai rata-rata siswa yang mengalami peningkatan yang signifikan. Pada hasil tes awal nilai rata-rata siswa hanya mencapai 60 . Nilai rata-rata siswa mengalami peningkatan pada tes siklus I menjadi 68, meningkat menjadi 78 pada siklus II. Pendekatan kontekstual dapat memberi kesempatan bagi siswa untuk berkompetisi di dalam menyusun karangan narasi sesuai dengan ciri-ciri karangan narasi. Perubahan tingkah laku atau sikap tampak dalam pembelajaran menyusun karangan narasi.
\end{abstract}

Kata kunci: Menulis karangan narasi, pendekatan kontekstual, inspirator lingkungan sekolah

\title{
A. PENDAHULUAN
}

Pembelajaran bahasa Indonesia menekankan pada pemerolehan empat keterampilan berbahasa. Keempat keterampilan tersebut adalah keterampilan menyimak, berbicara, membaca dan menulis. Keempat keterampilan berbahasa disajikan secara terpadu namun dimungkinkan untuk memberikan penekanan pada salah satu keterampilan menulis. Keterampilan menulis merupakan keterampilan yang bersifat produktif, artinya keterampilan menulis merupkan keterampilan yang menghasilkan tulisan. Menulis secara umum dapat diartikan sebagai suatu kegiatan penyampaian pesan atau komunikasi dengan menggunakan bahasa tulis sebagai alat atau medianya.

Menulis merupakan kegiatan yang kompleks karena penulis dituntut untuk dapat menyusun dan mengorganisasikannya dalam formulasi ragam bahasa tulis. Dibalik kerumitannya, menulis mengandung banyak manfaat bagi pengembangan mental, intelektual dan sosial siswa (Suparno dan Mohammad Yunus, 2007:3). Melalui kegiatan menulis paragraf siswa dapat mengkomonikasikan ide/gagasan dan 
pengalamannya. Siswa juga dapat meningkatkan dan memperluas pengetahuannya melalui tulisan-tulisannya. Di samping itu ada beberapa manfaat yang dapat dipetik/diperoleh dari menulis, antara lain (1) peningkatan kecerdasan, (2) pengembangan daya inisiatif dan kreatifitas, (3) menumbuhkan keberanian, dan (4) pendorong kemauan dan kemampuan mengumpulkan informasi (Suparno dan Mohammad Yunus, 2007:4).

Bahasa sebagai alat komunikasi memiliki empat fungsi. Keempat fungsi tersebut yakni (1) fungsi informasi, (2) fungsi ekspresi diri, (3) fungsi adaptasi dan integrasi dan (4) fungsi kontrol sosial (Santosa dkk, 2006:156). Alat bahasa yang terpenting adalah bunyi walaupun kemudian ditemukan ada juga media tulisan. Bahasa bersifat manusiawi karena bahasa menjadi berfungsi selama manusia yang memanfaatkannya, bukan makhluk lainnya. Bahasa disebut sebagai alat komunikasi karena fungsi bahasa sebagai penyatu keluarga, masyarakat, dan bangsa dalam segala kegiatannya. Setiap bahasa memiliki fungsi khusus. Demikian juga bahasa Indonesia sebagai bahasa nasional mempunyai fungsi khusus yang sesuai dengan kepentingan bangsa Indonesia. Bahasa merupakan sarana komonikasi yang sangat penting dalam kehidupan manusia. Kadar komonikasi seseorang akan terlihat pada kualitas keterampilan berbahasa yang dimilikinya. Dalam bahasa tulis, kualitas keterampilan berbahasa seseorang tergantung pada kemampuan menulis. Semakin baik kemampuan menyusun kalimat yang dimilikinya, semakin besar pula kemungkinan seseorang terampil menulis. Memahami hal tersebut, dapat dimengerti betapa pentingnya pembelajaran kalimat yang bersistem dan bervariasi di sekolah-sekolah sedini mungkin, untuk meningkatkan keterampilan menulis siswa.

Kemampuan menulis siswa SMP Negeri 1 Brang Rea masih tergolong rendah. Padahal, kemampuan di bidang ini sangat bermanfaat dalam menunjang kemampuan berbahasa siswa, dan terlebih lagi dalam menghadapi ujian nasional dengan tipe soal yang sudah mengarah pada aspek penggunaan bahasa. Oleh karena itu, kemampuan menulis sangat penting dan mendesak dikuasai siswa. Berdasarkan hasil observasi awal dan wawancara dengan siswa SMP Negeri 1 Brang Rea, diperoleh informasi bahwa kemampuan tentang menulis karangan narasi siswa masih rendah. Penyebab rendahnya kemampuan menulis siswa SMP Negeri 1 Brang Rea adalah sebagai berikut: (1) siswa sangat jarang diberikan kesempatan mengembangkan kemampuan menulis; (2) siswa lebih sering disuruh menghafal jenis-jenis karangan, tanpa diminta mencoba menulis atau menyusun karangan; (3) pelajaran menulis masih ditakuti siswa; (4) pelajaran menulis membosankan bagi siswa. Rendahnya kemampuan siswa dalam menulis terutama dalam menulis karangan narasi terbukti dari nilai rata-rata kelas yang diperoleh dalam pembelajaran menulis karangan narasi siswa hanya 70 . Nilai rata-rata tersebut belum memenuhi standar Kriteria Ketuntasan Minimal (KKM) untuk mata pelajaran bahasa Indonesia yang telah ditetapkan di SMP Negeri 1 Brang Rea yaitu 75. Oleh karena itu, kemampuan menulis karangan narasi siswa di kelas VIII SMP Negeri 1 Brang Rea perlu ditingkatkan.

Dari masalah yang dihadapi guru dan siswa di kelas VIII, khusunya kelas VIII1 SMP Negeri 1 Brang Rea, maka perlu dicarikan upaya untuk mengatasi permasalahan tersebut. Tindakan yang dianggap dapat mengatasi permasalahan 
tersebut adalah dengan mengubah desain pembelajaran. Desain pembelajaran yang dianggap mampu mengatasi permasalahan tersebut adalah menerapkan pembelajaran kontekstual (Contextual Teaching and Learning (CTL). Secara teoritis, dengan pendekatan kontekstual, pembelajaran akan berjalan lebih produktif dan bermakna, karena proses pembelajaran berlangsung alamiah dan bentuk kegiatan siswa bekerja dan mengalami, bukan transfer pengetahuan dari guru ke siswa (Depdiknas, 2003:1).

\section{B. METODE PENELITIAN}

Penelitian ini termasuk dalam penelitian tindakan kelas (PTK). Penelitian jenis ini mengikutsertakan perencanan yang memiliki bersifat reflektif mandiri secara terus menerus. maka, proses pelaksanaan penelitian ini merupakan langkahlangkah yang siklusif. Sesuai dengan prinsip dasar penelitian tindakan umumnya, setiap tahapan dan siklusnya selalu dilakukan secara partisipatoris dan kolaboratif antara peneliti dengan rekan guru yang serumpun di SMP Negeri 1 Brang Rea. Proses pelaksanaan tindakan dilakukan dalam empat tahapan secara berdaur ulang yang berawal dari (1) perencanaan, (2) pelaksanaan, (3) observasi, (4) refleksi. Semua langkah penelitian dirangkai menjadi suatu prosedur penelitian yang utuh, dimulai dari perencanaan atau persiapan tindakan yang dilakukan dalam rangka pelaksanaan penelitian. Beberapa hal perlu direncanakan secara baik, antara lain adalah (1) membuat skenario pembelajaran yang berisikan langkah-langkah kegiatan dalam pembelajaran yang berisikan langkah-langkah kegiatan yang akan dilakukan, (2) mempersiapkan sarana pembelajaran yang mendukung terlaksananya tindakan. Sarana pembelajaran ini dapat berupa perangkat lembar kerja siswa (LKS), (3) mempersiapkan instrumen penelitian, misalnya untuk mengobservasi proses kegiatan dan hasil pembelajaran, (4) melakukan simulasi pelaksanaan tindakan dan mengaji keterlaksanaannya di lapangan. Selanjutnya diuraikan pula bagaimana rencana pelaksanaan tindakan, rencana observasi, analisis data, evaluasi dan refleksi

\section{HASIL DAN PEMBAHASAN}

Penelitian tindakan kelas ini dimulai dengan melakukan observasi awal. Kegiatan ini melakukan observasi kemampuan siswa dalam proses pembelajaran bahasa Indonesia di kelas. Kegiatan ini bertujuan untuk mengetahui kemampuan menulis siswa dalam pembelajaran bahasa Indonesia di SMP Negeri 1 Brang Rea, khususnya kelas VIII-1. Pada kegiatan pratindakan ini, guru melaksanakan proses belajar-mengajar seperti biasa dan peneliti mengamati pembelajaran yang terjadi di kelas sebagai partisipan pasif. Setelah selesai menyampaikan materi mengenai langkah-langkah menyusun karangan seperti menentukan tema, judul, membuat kerangka karangan, dan mengembangkan kerangka karangan, kemudian guru melaksanakan tes untuk mengetahui tingkat keterampilan menulis narasi berdasarkan pengalaman siswa.

Secara terinci, pembelajaran menulis narasi yang dilakukan guru pada saat pembelajaran berlangsung yaitu (1) guru menjelaskan langkah-langkah menyusun kerangka karangan, siswa diharuskan mencatat sambil memperhatikan, (2) guru mendekati siswa dengan memberikan penjelasan berupa contoh kerangka karangan 
beserta pengembangannya yang ditulis di papan tulis, (3) guru menugaskan siswa untuk menulis berdasarkan pengalaman dengan judul yang telah ditentukan, (4) guru mengharuskan siswa untuk mengembangkan kerangka karangan menjadi empat alinea, (5) guru mengumpulkan hasil karangan yang telah ditulis siswa seadanya, dan (6) guru menilai hasil karangan siswa.

Berdasarkan hasil karangan siswa kelas VIII-1 SMP Negeri 1 Brang Rea dikategorikan rendah. Hal tersebut dapat dilihat dari beberapa indikator antara lain: (1) siswa belum mampu mengorganisasikan gagasan secara lancar dan runtut, (2) perbendaharaan kata (kosa kata) yang dimiliki siswa terbatas, sehingga banyak siswa yang mengulang kata-kata yang sama dalam satu alinea, (3) belum mampu memilih kata (diksi) secara tepat, dan (4) kurangnya kemampuan siswa dalam mengembangkan paragraf. Hal ini dapat dilihat dari hasil pekerjaan yang diberikan guru pada saat survei awal sebagian besar siswa memperoleh nilai yang tidak memuaskan.

Sebelum melakukan penelitian lebih jauh terkait dengan karangan narasi, peneliti memberikan tes awal atau percobaan terkait kemampuan siswa menulis karangan narasi. Hasil dari tes awal terkait kemampuan siswa menulis karangan narasi, nilai rata-rata yang diperoleh dari pelaksanaan tes awal adalah 60 dari 24 orang siswa yang diberi tes, hanya dua orang siswa memperoleh nilai di atas standar kriteria ketuntasan minimal (KKM), 22 orang siswa memperoleh nilai di bawah KKM. KKM mata pelajaran bahasa Indonesia kelas VIII SMP Negeri 1 Brang Rea adalah 75. Untuk lebih jelasnya, terkait dengan hasil tes awal menulis karangan narasi siswa SMP Negeri 1 Brang Rea dapat dicermati pada tabel berikut.

Hasil dari tes awal terkait kemampuan siswa menulis karangan narasi, nilai rata-rata yang diperoleh dari pelaksanaan tes awal adalah 60 dari 24 orang siswa yang diberi tes, hanya dua orang siswa memperoleh nilai di atas standar kriteria ketuntasan minimal (KKM), 22 orang siswa memperoleh nilai di bawah KKM. KKM mata pelajaran bahasa Indonesia kelas VIII-1 SMP Negeri 1 Brang Rea adalah 75. Berdasarkan hasil observasi awal yang dilakukan, maka beberapa temuan yang menonjol dan berpengaruh langsung terhadap peningkatan mutu pembelajaran karangan narasi. Berdasarkan temuan tersebut peneliti perlu mencarikan upaya untuk mengatasi permasalahan tersebut. Tindakan yang dianggap dapat mengatasi permasalahan tersebut adalah dengan mengubah desain pembelajaran. Desain pembelajaran yang dianggap mampu mengatasi permasalahan tersebut adalah menerapkan pembelajaran kontekstual. Secara teoritis, dengan pendekatan kontekstual pembelajaran akan berjalan lebih produktif dan bermakna, karena proses pembelajaran berlangsung alamiah dan bentuk kegiatan siswa bekerja dan mengalami, bukan transfer pengetahuan dari guru ke siswa.

Pelaksanaan proses belajar-mengajar yang dilakukan pada siklus I, masih ditemukan adanya kelemahan, namun di samping itu, sudah adanya kemajuan siswa dalam menulis karangan narasi jika dibandingkan dengan pelaksanaan tes awal. Berdasarkan hasil observasi didapatkan beberapa hal yang berdampak positif yang dapat mendukung pencapaian tujuan pembelajaran secara maksimal. Berdasarkan data observasi diperoleh hasil sebagai berikut: a) Apersepsi yang dilakukan oleh guru, dapat memberikan gambaran terhadap siswa tentang materi yang akan dipelajari; b) penyampaian kompetensi dasar dan manfaat pembelajaran, 
dapat berpengaruh positif terhadap siswa, karena mereka dapat mengetahui manfaat dari materi yang dipelajari terutama dalam menunjang kehidupannya kelak; c) memberikan peluang tanya jawab amat mendukung terhadap pemecahan masalah yang belum dipahami; d) dalam pembelajaran menulis karangan narasi dengan menggunakan pendekatan kontekstual terlihat siswa cukup antusias dan bergairah. Kegairan ini terlihat ketika siswa disuruh oleh guru (peneliti) untuk menulis karangan narasi, kemudian secara bergilir membacakan karangan narasi tersebut di depan kelas; e) pemberian penguatan terhadap siswa dengan kata "bagus, tepat sekali", dan acungan jempol sangan efektif untuk lebih memotivasi kreativitas siswa; f) siswa senang dan sangat tertarik pembelajaran menulis karangan narasi dengan pendekatan kontekstual, karena sambil belajar mereka dapat bermain dan berkelompok sebagai masyarakat belajar.

Hasil dari tes siklus I terkait kemampuan siswa menulis karangan narasi, nilai rata-rata yang diperoleh dari pelaksanaan siklus I adalah 68 dari 24 orang siswa yang diberi tes, hanya 7 orang siswa memperoleh nilai di atas standar kriteria ketuntasan minimal (KKM), 15 orang siswa memperoleh nilai di bawah KKM. KKM mata pelajaran bahasa Indonesia kelas VIII-1 SMP Negeri 1 Brang Rea adalah 75. Dari tes siklus I diperoleh nilai rata-rata sebesar 68. Terjadi peningkatan jika dibandingkan dengan hasil tes awal (hasil tes awal diperoleh rata-rata sebesar 60). Hasil dari tes siklus I terkait kemampuan siswa menulis karangan narasi, nilai ratarata yang diperoleh dari pelaksanaan siklus I adalah 68 dari 24 orang siswa yang diberi tes, hanya 7 orang siswa memperoleh nilai di atas standar kriteria ketuntasan minimal (KKM), 16 orang siswa memperoleh nilai di bawah KKM. KKM mata pelajaran bahasa Indonesia kelas VIII-1 SMP Negeri 1 Brang Rea adalah 75.

Agar penerapan metode kontekstual terlaksana dengan efektif diperlukan kesungguhan guru untuk berinovasi dan kreatif. Selain itu siswa SMP Negeri 1 Brang Rea masih membutuhkan bimbingan guru baik secara klasikal maupun individual. Hal ini diperlukan mengingat kondisi mental dan intelektual siswa SMP Negeri 1 Brang Rea tergolong rendah. Untuk bimbingan bagi siswa SMP Negeri 1 Brang Rea sangat diperlukan. Bimbingan klasikal kepada siswa secara psikologis mengingatkan rasa kebersamaan dalam diri mereka. Di samping itu, bimbingan klasikal juga sangat membantu guru dalam penyampaian berbagai permasalahan secara umum. Sedangkan, bimbingan individu memberikan kesempatan kepada guru untuk memberikan kesempatan kepada guru untuk memberikan bimbingan dalam dalam konsep orang per orang. Hal ini penting sebab dalam sebuah kelas, setiap individu memiliki latar belakang yang berbeda, baik dari segi intelektualitas, sikap, dan prilaku, maupun cara mereka dalam memandang materi yang diajarkan guru. Dengan kata lain, proses penyerapan isi materi yang diajarkan juga beragam. Untuk mampu menciptakan keseragaman itulah maka bimbingan sangat diperlukan.

Hal yang juga tidak kalah pentingnya dalam proses pembelajaran menulis karangan narasi dengan pendekatan kontekstual yaitu pemberian penguatan secara intensif kepada siswa setelah selesai melakukan kegiatan, kerena pemberian penguatan baik secara verba/ maupun non verbal yakni berupa kata "bagus", "tepat sekali", atau acungan jempol maupun anggukan kepala akan dapat menumbuhkan rasa percaya diri dan menambah keyakinan terhadap dirinya sendiri akan kemampuan yang dimilikinya. 
Nilai rata-rata yang diperoleh dari tes tindakan II adalah 75.8. Dari 24 orang siswa yang diberikan tes diperoleh hasil sebagai berikut: 19 orang siswa memperoleh nilai 80 ; 5 orang mendapat nilai 70 Nilai KKM mata pelajaran bahasa Indonesia SMP Negeri 1 Brang Rea ditetapkan sebesar 75. Pada tindakan siklus II sudah ada peningkatan kemampuan siswa, ini terbukti dengan hasil nilai 19 orang siswa mendapatkan nilai di atas KKM, yakni nilai 80. Namun, masih ada 5 orang siswa hasil tes siklus II paling rendah (masih di bawah KKM 75), yakni memperoleh nilai 70.

Berdasarkan refleksi akhir yang dilakukan, maka dari kedua siklus yang telah dilaksanakan ditemukan bahwa siswa senang dengan pembelajaran model ini. Pertama, selain sederhana dan memudahkan juga menantang dan dapat memacu siswa untuk aktif dan kreatif. Kedua, model pembelajaran seperti ini cocok untuk siswa yang berusia belasan tahun, karena pada usia tersebut mereka masih memerlukan permainan. Dalam membuat karangan narasi siswa memerlukan tuntunan dan penjelasan guru yang menyangkut pengertian karangan narasi, penggunaan huruf kapital, tanda baca, penggunaan bahasa dan aspek isi. Ketika siswa membuat karangan narasi dengan tema tertentu, siswa memerlukan bimbingan, baik secara klasikal maupun individual.

Berdasarkan perumusan masalah dan hasil tindakan, maka tujuan yang ingin dicapai dalam penelitian, serta paparan hasil penelitian yang meliputi peningkatan proses keterampilan menulis narasi dengan pendekatan kontekstual siswa kelas VIII-1 SMP Negeri 1 Brang Rea. Penelitian tindakan ini dilaksanakan dalam dua siklus. Siklus pertama ini mendeskripsikan pembelajaran menulis narasi dengan menerapkan pendekatan kontekstual. Ternyata masih terdapat beberapa kekurangan atau kelemahan dalam pelaksanaannya. Siklus I merupakan siklus untuk memberikan solusi yang dilaksanakan untuk mengatasi kekurangan atau kelemahan yang ada selama proses pembelajaran menulis narasi dengan menerapkan pendekatan kontekstual. Selama pelaksanaan siklus I ini juga terdapat sedikit kelemahan. Kemudian, kelemahan pada siklus I ini dapat diatasi dengan melaksanakan pembelajaran menulis narasi dengan menerapkan pendekatan kontekstual pada siklus II. Selain itu siklus II merupakan siklus yang menguatkan hasil siklus I bahwa pendekatan kontekstual dapat meningkatkan kemampuan menulis karangan narasi siswa kelas VIII-1 Negeri Brang Rea.

Kemampuan siswa meningkat pada proses pembelajaran menulis karangan narasi dengan menggunakan pendekatan kontekstual. Pendekatan kontekstual dalam pembelajaran bahasa Indonesia dapat meningkatkan keterampilan menulis karangan narasi karena siswa terlibat aktif dalam proses pembelajaran, sehingga mempermudah siswa dalam merangkai kata menjadi sebuah karangan, pada awalnya siswa merasa kesulitan dalam menulis sebuah karangan. Namun, ketika guru menjelaskan materi dengan pendekatan kontekstual, siswa dengan antusias dan memperhatikannya, sehingga siswa dapat menulis karangan narasi dengan baik. Peningkatan tersebut dapat dilihat pada hasil postes, angket, dan jurnal siswa. Keterampilan menulis siswa meningkat pada siklus I diiringi dengan peningkatan rata-rata keseluruhan indikator yang terdapat dalam belajar. Penelitian diakhiri pada siklus III karena telah memenuhi kriteria keberhasilan penelitian. 
Seiring dengan meningkatnya kemampuan siswa dalam menulis karangan narasi karena terdapatnya sikap antusias, memperhatikan penjelasan guru, serta mengerjakan postes dengan sungguh-sungguh, membuat siswa lebih memahami materi yang telah dipelajari. Menurut hasil observasi serta hasil dari tindakan siswa lebih memahami materi menulis karangan narasi dengan pendekatan kontekstual. Berdasarkan data hasil belajar dengan menggunakan pendekatan kontekstual dapat meningkatkan keterampilan menulis siswa, khususnya karangan narasi.

\section{KESIMPULAN}

Pendekatan Kontekstual dapat meningkatkan mutu pembelajaran menulis karangan narasi siswa kelas VIII-1 SMP Negeri 1 Brang Rea, tahun pelajaran 2018/2019. Hal ini dapat dicermati dari perolehan nilai rata-rata siswa yang mengalami peningkatan yang signifikan. Pada hasil tes awal nilai rata-rata siswa siswa hanya mencapai 60 . Nilai rata-rata siswa mengalami peningkatan pada tes siklus I menjadi 68, meningkat menjadi 78 pada hasil tes siklus II. Demikian pula ketuntasan kelas, mengalami peningkatan dari tes awal yang mencapai $8.33 \%$, meningkat menjadi $29.17 \%$ pada hasil tes siklus I, meningkat menjadi $79.17 \%$ pada hasil tes siklus II. Pendekatan kontekstual dapat memberi kesempatan kepada siswa untuk berkompetisi di dalam menyusun karangan narasi sesuai dengan ciriciri karangan narasi. Perubahan tingkah laku atau sikap menjadi siswa yang kreatif tampak dalam pembelajaran menyusun karangan narasi. 


\section{DAFTAR RUJUKAN}

Depdiknas. 2005. Materi Pelatihan Terintegrasi Bahasa dan sastra Indonesia: Penelitian Tindakan Kelas. Jakarta: Depdiknas

Santoso, Puji. Dkk. 2006. Materi Pokok: Materi dan Pembelajaran Bahasa Indonesia 1-9 PGSD4405/3 SKS. Jakarta: Universitas Terbuka

Suparno, dan Muhammad Yunus. 2007. Panduan Kretif Bahasa Indonesia untuk SMP Kelas VIII. Bogor: Yudistira. 
ISSN Cetak: 2685-5542

ISSN Online: $2685-5550$ 